\title{
Correction to: Sound measurement and automatic vehicle classification and counting applied to road traffic noise characterization
}

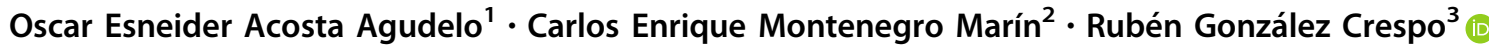

Published online: 7 May 2021

(c) Springer-Verlag GmbH Germany, part of Springer Nature 2021

\section{Correction to: Soft Computing}

https://doi.org/10.1007/s00500-021-05766-6

While typesetting the article there are several places the cross references are incorrect.

The original article has been updated.

Publisher's Note Springer Nature remains neutral with regard to jurisdictional claims in published maps and institutional affiliations.

The original article can be found online at https:// doi.org/10.1007/s00500-021-05766-6.

Rubén González Crespo

ruben.gonzalez@unir.net

Oscar Esneider Acosta Agudelo oeacostaa@correo.udistrital.edu.co

Carlos Enrique Montenegro Marín cemontenegrom@udistrital.edu.co

1 Ingeniería de Sonido, Facultad de Ingeniería, Universidad de San Buenaventura Bogotá, Universidad Distrital Francisco José de Caldas, Bogotá, Colombia

2 Facultad de Ingeniería, Universidad Distrital Francisco José de Caldas, Bogotá, Colombia

3 School of Engineering and Technology, Universidad Internacional de La Rioja, Logroño, Spain 